\section{Mr. H. J. Turner}

Henry Jerome TURner was the last of a circle of notable amateur British entomologists who, around the turn of the century, rediscovered and popularized the study of Europeun butterflies. The entomological journals of the period are full of descriptions of their doings in France, in the Alps, in Austria, Spain, the Balkans, Scandinavia and elsewhere, and these descriptions are all the more readable because the authors, while adding greatly to our detailed knowledge of the European fauna, remained very human and could write of the people and the scenery as well as the 'bugs'.

Turner was the only son of a Redhill builder and was born on August 27, 1856. By profession a schoolmaster, he early obtained a position under the London School Board and eventually became headmaster of Denmark Hill School, which by sheer hard work and strict discipline he turned before long into a model. He had early shown an interest in entomology; but it was not until he joined the South London Society in 1887 and came under the spell of J. W. Tutt that this interest was given point. Tutt was then engaged on his "Natural History of British Lepidoptera". Turner became one of his most devoted disciples, and after his death in 1911 took over the editorship of the Entomologist's Record, which Tutt had founded in a moment of frustration and iconoclastic frenzy in 1890. In 1894 he had become editorial secretary of the South London Society; this post too he held for some forty years. Not content, he shouldered responsibility for the Library of the Royal Entomological Society of London in 1921 and supervised its removal from Chandos Street and resuscitation at Queen's Gate in the succeeding years. He was elected honorary life president of the South London Society in 1944 and a special life fellow of the Royal Entomological Society in 1948.

It is perhaps not surprising that with so much to do Turner produced little original work. His most notable publications were largely of a bibliographical nature, such as his supplement to Tutt's "Varieties of the British Noctuae", which he commenced to issue in odd pages twenty-five years ago as a supplement to the Entomologist's Record, and now is unlikely ever to be finished. His "Butterflies of Cyprus" was his chief contribution to faunistic knowledge. A little man, bolt upright and of rather rigid views, Turner was every inch a schoolmaster and had been a figure in London entomological circles, and internationally, for more than sixty years when he passed away, still at work, on December 19, mourned by a very wide circle of friends.

N. D. RILEY

WE regret to announce the following deaths :

Prof. G. T. R. Evans, head of the Department of physics in the University of the Witwatersrand, on December 20.

Academician Sergei Vavilov, president since 1945 of the Academy of Sciences of the U.S.S.R., known for his work on photoluminescence, on January 25, aged fifty-nine.

\section{NEWS}

\section{Dr. H. Hamshaw Thomas, M.B.E., F.R.S.}

DR. HAMSHAW THOMAS, an international authority on palrobotany, who has been associated with the Botany School in the University of Cambridge for the past forty years, retired from his teaching posts in the University and in Downing College on September 30 last. Appointed curator of the Museum in 1909, he has taken an active part in the teaching of botany at Cambridge since that time, except for two periods of more than four years during the two World Wars, when, as a serving officer in the R.F.A., R.F.C. and R.A.F., he was concerned with the development of aerial photography and of air photographic intelligence. He was appointed a University lecturer in 1923 and reader in plant morphology in 1937. From 1920 he was secretary of the Botanic Garden Syndicate, and for many years assisted the professors of botany in the administration of the Department. During 1914-50 he held a fellowship at Downing College, and was director of biological studies there from 1919 onwards; he had also held the offices of dean and steward in his College, which has now elected him to an honorary fellowship. Dr. 'Thomas's scientific work was recognized by his election to the Royal Society in 1934, to the presidency of Section $K$ (Botany) of the British Association in 1947, and to the presidency of the Section for Palæobotany at the Seventh International Botanical Congress in 1950. $\mathrm{He}$ has also taken an active part in the promotion of the study of the history of science in Cambridge since 1935. Dr. Thomas's retirement from active teaching will, it is hoped, give him leisure to develop further those particular interests with which his name is associated.

\section{nd VIEW S}

Cambridge Botanic Garden : Mr. H. Gilbert-Carter

Mr. H. GILBert-Carter relinquished his positions as director of the Botanic Garden and University lecturer in botany, Cambridge, at the commencement of the present academic year, having reached the age of retirement. He had entered the University of Cambridge as a research student after taking a degree in medicine at Edinburgh, and later joined the staff of the Indian Botanical Survey. He returned from Calcutta to become director of the Botanic Garden at Cambridge in 1921; in the same year he was also appointed curator of the Herbarium in the Botany School. He held the latter post until 1930, when he was appointed a university lecturer. For more than twenty-five years he has been mainly responsible for the teaching of the taxonomy of the flowering plants at Cambridge, and he proved to be a most stimulating teacher. During his directorship the Botanic Garden passed through a long period of financial difficulty, relieved by generous gifts from Mr. Reginald Cory and other benefactors. In spite of this, the scientific and resthetic value of the Garden has been well maintained.

\section{Royal Horticultural Society's Gardens, Wisley:}

Mr. J. L. S. Gilmour

Mr. J. L. S. Grmour, director of the Royal Horticultural Society's Gardens at Wisley, who has been appointed to succeed Mr. Gilbert-Carter at the Cambridge University Botanic Garden, is well qualified for the post. For a short time after graduating at Cambridge he was curator of the University Herbarium, and during that period was in constant touch with work in the Botanic 